\title{
Kerajaan Minangkabau Sebagai Asal-usul Kesultanan Jambi
}

\author{
Arif Rahim \\ Fakultas Keguruan dan Ilmu Pendidikan Universitas Batanghari \\ Correspondence email: arifrahim35@yahoo.com
}

\begin{abstract}
Abstrak. Tulisan ini membahas tentang kerajaan Minangkabau dan keberadaannya sebagai asal-usul Kesultanan Jambi. Masalah ini dinilai penting karena saat ini banyak kalangan yang kurang memahami hubungan antar kerajaan pada masa lampau, yang mana daerah-daerah tersebut dewasa ini termasuk ke dalam wilayah kerajaan-kerajaan tersebut. Hasil penelitian ini diharapkan dapat memberi penjelasan terhadap masalah pokok yang diajukan dan seterusnya berkontribusi terhadap pengembangan ilmu pengetahuan terutama tentang sejarah lokal Jambi dan Sumatera Barat. Selain itu dapat dijadikan sebagai bahan pertimbangan oleh institusi terkait dalam rangka melestarikan nilai-nilai sejarah dan budaya dan untuk pengembangan dan pembangunan daerah. Dengan menggunakan pendekatan multidimensional dan didukung oleh penerapan motode sejarah yang mengacu ada prosedur penelitian sejarah ilmiah, diharapkan pertanyaan-pertanyaan yang diajukan dalam rumusan masalah akan dapat diungkapkan secara objektif dan sistematis. Hasil Penelitian menunjukkan daerah Minangkabau merupakan daerah tua yang telah didiami manusia setidaknya sejak zaman Batu Muda sekitar 2000 tahun SM. Di daerah kabupaten Lima Puluh Kota banyak ditemuan Menhir yang diperkirakan berasal dari masa tersebut. Daerah Minangkabau merupakan daerah tempat turunnya Sang Sapurba bergelar Datuk Maharaja Diraja yang dalam tradisi lisan dianggap sebagai nenek moyang suku Minangkabau dan rumpun Melayu pada umumnya dan juga sebagai sosok yang menurunkan raja-raja yang memerintah di Pulau Sumatra, terutama negeri-negeri Melayu. Dalam konteks hubungan Jambi dan Minangkabau, dapat dikatakan bahwa raja-raja yang memerintah di kerajaan Jambi adalah keturunan dari Kerajaan Minangkabau. Putri Selaro Pinang Masak yang dalam legenda kerajaan Jambi dipandang sebagai pendiri kerajaan Jambi adalah anak dari Ananggawarman yang memerintah di Pagaruyung pada tahun 1376 - 1417 M. Sebagai negeri tua, Minangkabau mempunyai sistem adat dan kebudayaan yang yang mempegaruhi daerah sekitarnya, termasuk daerah Jambi. Sumber Lembaga Adat Melayu Jambi mengatakan bahwa yang menyusun adat Jambi adalah Datuk Perpatih Nan Sabatang dari Pagaruyung sedangkan yang berasal dari Bandar Jambi adalah Datuk Ketemanggungan.
\end{abstract}

Kata kunci: kerajaan Minangkabau; asal usul; kesultanan Jambi

Abstract. This article discusses the Minangkabau kingdom and its existence as the origin of the Jambi Sultanate. This issue is considered important because at this time there are many people who do not understand the relationship between the kingdoms in the past, which regions are currently included in the kingdoms of these kingdoms. The results of this study are expected to provide an explanation of the main problems proposed and so contribute to the development of knowledge, especially about the local history of Jambi and West Sumatra. Besides, it can be used as material for consideration by related institutions in order to preserve historical and cultural values and for regional development and development. By using a multidimensional approach and supported by the application of historical methods that refer to scientific historical research procedures, it is hoped that the questions raised in the formulation of the problem will be objectively and systematically expressed. The results showed that the Minangkabau area was an old area that had been inhabited by humans at least since the Batu Muda era around 2000 years BC. In the district of 50 Kota there are many Menhir findings which are thought to be from that period. The Minangkabau area is the area where Sang Sapurba's title Datuk Maharaja Diraja descended which in oral tradition is considered the ancestor of the Minangkabau tribe and the Malay family in general and also as a figure who descended the kings who ruled on the island of Sumatra, especially the Malay countries. In the context of Jambi and Minangkabau relations, it can be said that the kings who ruled in the Jambi kingdom were descended from the Minangkabau Kingdom. Putri Selaro Pinang Masak, who in the Jambi royal legend is seen as the founder of the Jambi kingdom, was the son of Ananggawarman who ruled in Pagaruyung from $1376-1417$ $A D$. As an old country, Minangkabau has a customary and cultural system that affects the surrounding area, including the Jambi area. A source from the Jambi Malay Customary Institute said that the one who composed Jambi's customs was Datuk Perpatih Nan Sabatang from Pagaruyung, while those from Bandar Jambi were Datuk Ketemanggungan

Keyword: minangkabau kingdom; origin; Sultanate of Jambi

\section{PENDAHULUAN}

Pulau Sumatera adalah pulau terbesar setelah pulau Kalimantan di antara ribuan pulau yang tersebar di suatu kawasan yang disebut Nusantara. Dari segi penduduk pulau ini juga mempunyai jumlah penduduk kedua terbanyak setelah pulau Jawa. Dari segi geografis letaknya adalah yang paling strategis karena terletak di jalur perdagangan yang menghubungkan dua kawasan penting sepanjang sejarah yakni Arab dan India di sebelah barat serta Cina dan Jepang di timur dan utara. Selama berabad-abad lamanya kawasan-kawasan tersebut telah menjalin hubungan dengan Sumatera. Kerajaan-kerajaan besar seperti Sriwijaya, Melayu, Aceh terletak di pulau ini. Pada bagian pendahuluan disertasinya Elizaberth E. Graves (2007) melukiskan penduduk Sumatera memiliki tingkat mobilitas individual yang tinggi, melakukan perjalanan jauh untuk berniaga, atau satu waktu melakukan penjarahan, 
menjadi bajak laut. Banyak penduduknya yang melakukan pelayaran jauh, bahkan sampai ke pantai timur Afrika dan di sana mereka bergabung dalam pemukiman Melayu Madagaskar.

Dengan demikian Sumatera secara historis merupakan pulau dengan penduduk gemar berdagang dan dinamis, menjadi arena percaturan politik dan internasional, atau persaingan prestasi individual. Orang Minangkabau di Sumatera Barat khususnya adalah pewaris terhormat dari tradisi yang sudah sangat tua itu (Graves, 2007).

Pernyataan Graves (2007) itu cukup sebagai alasan pentingnya mengkaji Kerajaan Minangkabau. Tak dapat disangkal kerajaan inilah sebagai penerus dua kerajaan besar Nusantara selama sepuluh abad sebelumnya yakni Sriwijaya dan Melayu. Ketika didirikan oleh Adityawarman tahun 1349 kerajaan yang berpusat Pagaruyung Batusangkar sekarang, menguasai daerah yang luas meliputi daerah Provinsi Sumatera Barat sekarang, daerah pantai timur Arcat (daerah antara Aru dan Rokan hingga Jambi, serta di pantai barat yakni daerah Muko-muko (sekarang Bengkulu hingga Barus di Sumatera Utara (Tome Pires, 2016). Selain itu ada daerah pengaruh yaitu daerah yang mengakui kedaulatan Pagaruyung namun tak diharuskan membayar upeti. Terdapat 62 kerajaan di Nusantara yang tersebar di Filipina, Brunai, Thailand dan Malaysia, hampir seluruh Pulau Sumatera, Nusa Tenggara Barat dan Nusa Tenggara Timur. Kerajaan-kerajaan itu mengaku menginduk ke Pagaruyung. Gradasi hubungannya dalam bentuk sapiah-balahan (keturunan dari garis ibu), kuduang karatan (keturunan dari garis ayah), timbangpacahan, dan kapak radai yang merupakan keturunan kerajaan (Kompas. 22 Juni 2013). Ketika menobatkan dirinya sebagai raja Adityawarman mamakai gelar Maharajadiraja, suatu gelar yang lazim digunakan oleh kerajaan besar dan berdaulat sendiri.

Kebesaran Minangkabau ditopang oleh keadaan alamnya yang subur dan kaya dengan bahan tambang terutama emas. Daerah ini adalah penghasil lada terbesar yang menjadi komoditas yang paling berharga dalam perdagangan dunia selama berabad-abad.

Selain pedagang, orang-orang Minangkabau juga terkenal sebagai pendakwah dan penyebar agama Islam di Nusantara. Seorang pangeran Pagaruyung yang bernama Raja Baginda beserta pengikutnya dikenal sebagai orang yang mula-mula menyebarkan agama Islam di Philipina (https://id.wikipedia.org/wiki/Islam di Filipina). Di Sulawesi Selatan Islam disebarkan oleh tiga orang Datuk beserta pengikutnya. Ketiganya dikenal sebagai ahli huhum (Fiqih), ahli tauhid dan ahli tasauf. Yang pertama bernama Dt. Ribandang yang nama aslinya adalah Abdul Makmur Khatib Tunggal, berdakwah di daerah Goa, Talo, Sepang, Wajo, Gantarang, Kutai dan Bima. Selanjutnya Dt. Patimang atau Dt. Sulaiman Khatib Sulung, berdakwah di kerajaan-kerajaan Luwu, Kolaka, Tana Toraja dan Poso. Yang ketiga Nurdin
Aryani Khatib Bungsu, berdakwah di daerah selatan yakni Tiro, Bulukumba, Bantaeng dan Tanete (https://id.wikipedia.org/wiki/Datuk_ri_Bandang).

Hingga sekarang nama ketiga ulama tersebut sangat dihormati di Sulawesi. Pemerintah kabupaten Bulukumba mengabadikan nama Datuk Ri Tiro sebagai nama Islamic Center Bulukumba.

Penyebaran Islam di Sulawesi Tengah juga pertama kali dilakukan oleh seorang ulama asal Minangkabau bernama Datuk Karama. Nama aslinya adalah Syekh Abdullah Raqie, pertama kali menyebarkan agama Islam ke Tanah Kaili atau Bumi Tadulako, Sulawesi Tengah pada abad ke-17. Awal kedatangan Syekh Abdullah Raqie atau Datuk Karama di Tanah Kaili bermula di Kampung Lere, Lembah Palu (Sulawesi Tengah) pada masa Raja Kabonena, Ipue Nyidi memerintah di wilayah Palu. Selanjutnya Datuk Karama melakukan syiar Islam-nya ke wilayah-wilayah lainnya di lembah Palu yang dihuni oleh masyarakat Suku Kaili. Wilayah-wilayah tersebut meliputi Palu, Donggala, Kulawi, Parigi dan daerah Ampana (https://id.wikipedia.org/wiki/Datuk_Karama).

Rombongan Datuk Karama yang lain bernama Datuk Mangaji yang berdakwah di daerah Parigi (https://id.wikipedia.org/wiki/Datuk_Mangaji).

(Masyarakat Sulawesi Tengah sangat menghormati ulama ini. Sebagai penghargaan nama Datuk Karama dijadikan sebagai nama perguruan tinggi yaitu IAIN Datokarama Palu.

Dalam konteks sejarah Jambi Raja-raja Minangkabau adalah leluhur yang menurunkan raja-raja yang memerintah di wilayah Jambi yang dikenal dengan sebutan Bumi Sepucuk Jambi Sembilan Lurah. Pernyataan itu dapat dikatakan fakta kuat karena seluruh penutur maupun penulis sejarah Jambi menyatakan keturunan raja Jambi berasal dari Pagaruyung.. Masalahnya kini adalah banyak masyarakat yang kurang memahami tentang jalinan sejarah antar daerah sehingga timbul kesan seolah-olah masing-masing daerah punya sejarah sendiri yang terlepas dari daerah lain. Pemberlakuan otonomi daerah sejak zaman reformasi semakin menguatkan kesan tersebut, karena masingmasing daerah berupaya mencari "icon" atau identitas daerah.

Sehubungan dengan uraian di atas maka rumusan masalah yang diajukan dalam penelitian ini adalah berupa pertanyaan, bagaimana keberadaan Kerajaan Minangkabau sebagai asal-usul dari kesultanan Jambi. Secara spasial pembahasan dalam penelitian ini mencakup bahasan tentang proses terbentuknya kerajaan Minangkabau beserta pengaruhnya terhadap masyarakat Minangkabau di daerah luhak maupun rantau, menyangkut aspek sosial, ekonomi maupun politik. Aspek lainnya menyangkut asal-usul kesultanan Jambi dengan menitikberatkan penjelasan seputar perkembangan kesultanan Jambi pada masa awal. Selanjutnya secara temporal pembahasan topik ini berkisar pada periode sekitar abad 14 dan15. Abad 14 
adalah masa terbentuknya Kerajaan Minangkabau sedangkan abad 15 adalah masa berdirinya Kesultanan Jambi.

Tulisan ini bertujuan menjelaskan keberadaan Kerajaan Minangkabau sebagai cikal-bakal kerajaan hubungan Kesultanan Jambi. Hali itu didorong oleh keadaan masih kurangnya hasil kajian tentang sejarah lokal Jambi, sementara masalah-masalah kesejarahan terutama pada rentang waktu prakolonial masih banyak yang belum terungkap. Dengan demikian hasil tulisan ini diharapkan menjadi uraian objektif yang dapat memperkaya khasanah pengetahuann terutama menyangkut dinamika hubungan antara Jambi dan Minangkabau. Dengan melakukan penggalian dan penelusuran data-data sejarah, hasil penelitian ini diharapkan dapat mengungkap sejarah kerajaan-kerajaan zaman kuno di daerah Jambi sekaligus sebagai refleksi dan bahan pertimbangan dari instansi terkait dalam mengambil keputusan atau kebijakan terutama apa bila hal demikian terkait dengan persoalan kesejarahan

\section{Kerangka Teoritis}

Bersandar pada teori set of sets yang digunakan oleh K.N Chaudhuri dalam membahas jalur perdagangan Samudera Hindia, sejarawan Universitas Indonesia R.Z Leirissa (1997) menyatakan bahwa sejarah Asia antara abad 7 hingga abad 18 dtafsirkan sebagai suatu proses sejarah yang berlangsung lebih dari satu milinium, dimana laut, lahan subur, gunung-gunung dan gurun, merupakan elemen-elemen dasar dalam suatu kawasan tempat terjadi interaksi antara, para pelaut, para nomad dan para petani. Pemikiran seperti itu memungkinkan adanya suatu prinsip dimana setiap elemen dari berbagai set seperti samudera Hindia, orang-orang Arab, orangorang India, orang-orang Cina dan lain sebagainya dipadukan dalam pola sejarah yang sama. Jalur ini dikenal dengan jalur sutera berfungsi menyalurkan produk-produk dari timur ke Barat. Alat utamanya adalah "karavan" yaitu rombongan onta dalam jumlah yang sangat besar.

Terbentuknya jalur perdagangan transkontinental yang membentang di Asia Tengah yang menghubungkan Chang-an (Ibukota Cina sejak abad 17 hingga abad 13) dengan wilayah-wilayah sekitar laut Kaspia, serta dengan Mesopotamia, dan pelabuhan Antiochia di pantai Laut Tengah, adalah satu adalah satu pola sejarah. Jalur ini dikenal dengan jalur sutera, berfungsi menyalurkan produk-produk dari timur ke barat. Alat utamanya adalah "karavan" yaitu rombongan onta dalam jumlah yang sangat besar. Demikian pula halnya dengan jalur laut yang menghubungkan negeri pantai Laut Tengah di barat dengan dengan Cina di sebelah timur, melalui Laut Merah, Teluk Parsi, Samudera Hindia, Selat Malaka, Selat Sunda, dan Laut Cina Selatan. Sejarawan menyebut jalur ini dengan sebutan jalur pelayaran niaga karena berfungsi sama dengan jalur sutera (Leirissa, 1997).
Berdasarkan teori tersebut kemunculan kerajaan Minangkabau, Melayu dan Sriwijaya dapat dihubungkan dengan keberadaan Selat Malaka dan Samudera Hindia yang berfungsi sebagai jalur pelayaran niaga tersebut. Jalur perdagangan itu dipengaruhi oleh sistem angin di Asia tropis (Reid, 1992). Keteraturan itu dimanfaatkan oleh para pemilik kapal untuk kepentingan pelayaran. Apabila hendak melakukan pelayaran jarak jauh, para pemilik kapal berusaha mengurangi resiko pelayaran dengan cara menentukan waktu yang baik dan mengikuti arah angin. Pada bulan Januari-Februari dapat dipastikan bertiup angin utara yang dimanfaatkan oleh kapal-kapal Cina, Jepang, dan Ryukyu untuk berlayar ke selatan. Mereka kembali ke utara ketika bertiup angin dari arah selatan ada bulan Juni, Juli dan Agustus. Kapal-kapal Arab dan India akan berlayar ke Nusantara dengan memanfaatkan angin musim barat antara bulan Aprilhingga Agustus. Kebanyakan dari mereka tinggal untuk berdagang sembari menunggu datangnya angin musim timur dan datangnya kapal-kapal Cina antara bulan Desember hingga April. Menurut Anthony Reid (1992) pelayaran yang berdasarkan angin musim inilah yang mengakibatkan lahirnya bandar-bandar perdagangan. Memperkuat pendapat Reid (1992) ini O.W Wolters mengatakan bahwa munculnya kerajaankerajaan masa awal di Asia Tengara (termasuk Melayu) merupakan akibat reaksi penduduk setempat yang menggunakan kesempatan yang diberikan oleh pedagang asing (Lapian, 1997). Rupanya penduduk lokal nusantara telah memanfaatkan jalur lalu lintas yang berbasis perdagangan itu untuk mencptakan wilayah-wilayah kekuasaan di sepanjang jalur perdagangan tersebut. Dalam konteks kerajaan Minangkabau yang berada di pedalaman Sumatera, hal demikian lebih memungkinkan karena dari wilayahnya mengalir sungaisungai besar seperti Rokan, Siak, Kampar, Indragiri dan Batanghari yang berfungsi sebagai jalan raya menghubungkan daerah pantai timur Sumatera (Jambi dan Riau) dengan kawasan hulu (Minangkabau) yang merupakan daerah subur yang sangat kaya dengan berbagai produk komoditas perdagangan . Teori ini berlaku umum sebagai pendorong munculnya pusatpusat kekekuasaan di sepanjang jalur strategis, akan tetapi mengenai eksistensi dan jatuh bangunnya pusatpusat kekuasaan sangat ditentukan oleh dinamika internal kawasan seperti peperangan, dan penuklukanpenaklukan yang dilakukan oleh kekuatan yang lebih kuat. Sebagaimana halnya dengan munculnya kerajaankerajaan Turki di Asia Barat dan Moghul di India adalah buah dari ekspansi kekuasaan bangsa Mongol dari Asia Tengah (Leirissa, 1997).

Untuk melihat Kerajaan Minangkabau sebagai asal-usul kesultanan Jambi digunakan konsep “ geneologi “ yaitu pengetahuan mengenai asal-usul moyang atau keturunan keluarga seseorang atau orangorang. Dahulu kaisar-kaisar, raja-raja, atau orang terkemuka biasa membuat pohon (family tree) untuk menunjukkan asal-usulnya. Dalam konteks penelitian 
orang-orang tertentu yang menjadi objek penelitian dapat dilakukan melalui biodata atau curriculum vitae nya (Sjamsuddin, 2007).

\section{METODE}

Jenis penelitian ini adalah penelitan kepustakaan (library research), yaitu serangkaian penelitian yang berkenaan dengan metode pengumpulan data pustaka, atau penelitian yang obyek penelitiannya digali melalui beragam informasi kepustakaan (buku, ensiklopedi, jurnal ilmiah, koran, majalah, dan dokumen). (Nana Syaodih, 2009)

\section{HASIL DAN PEMBAHASAN}

\section{Asal-usul dan Kehidupan Awal Suku Minangkabau}

Berdasarkan lingkaran-lingkaran hukum adat yang disusun oleh Van Vollenhoven, suku bangsa Minangkabau adalah salah satu dari 19 suku utama yang mendiami wilayah Indonesia (Koentjaraningrat, 2009). Meski demikian kurun panjang keberadaan suku ini sulit dijelaskan berdasarkan standar pengetahuan ilmiah. Sejarahnya mulai terungkap agak terang sejak abad ke 14. Sedangkan untuk masa sebelumnya tidak ditemukan peninggalan tertulis, kecuali hanya peninggalanpeninggalan arkeologis yang jumlahnya pun tak seberapa.

Beruntung suku Minangkabau sangat kaya dengan tradisi lisan. Di antaranya, yang paling lengkap penggambarannya adalah tambo atau tarombo. Melalui tambo itulah masa silam Minangkabau dapat tergambar. Di dalamnya digambarkan tentang asal usul suku Minangkabau, proses penyebarannya, wilayah kekuasaan, serta aturan-aturan yang dijadikan pegangan dalam kehidupan masyarakat.

Dalam perspektif historiografis tambo tergolong bentuk historiografi tradisional. Salah satu ciri yang melekat padanya adalah kuat dalam hal geneologi, tetapi lemah dalam hal kronologi dan detil-detil biografis (Taufik Abdullah, 1985). Edward Jamaris (1991) mengklasifkaikasikan tambo sebagi karya sastra. Bila dikaitkan dengan sejarah dinilai hanya mengandung $2 \%$ fakta (Mansur, 1970). Namun perkembangan metodologi penelitian sejarah dewasa ini memungkinkan orang untuk menyusun sejarah dengan memanfaatkan sumber tradisi lisan. Sebagian besar penulisan sejarah Afrika untuk kurun sebelum kedatangan bangsa-bangsa Eropa paling banyak menggunakan sumber tradisi lisan (Vansina, 2014).

Tradisi lisan Minangkabau mengatakan bahwa nenek moyang mereka adalah keturunan Iskandar Zulkarnain dari Yunani. Dalam sebuah tambo dikatakan

Lorong nan niniak mujang kito, asa usuanjo kalau dikaji, di dalam tarambo lamo, sapiah balahan tigo djurai asa nan dari banua Ruhum. Nan tuo Maharadjo Alif, nan tingga di banua ruhum, nan tangah Maharadjo Depang nan jatuah ka banua Tjino, nan bungsu Maharadjo Diradjo nan turun ka pulau ameh nangko. Dalam hal nenek moyang kita, bila dikaji asal-usulnya, serpihbelahan tiga jurai, yang tua bernama Maharaja Alif, tinggal di Romawi , yang tengah namanya Maharaja Depang jatuh ke Negeri Cina, dan yang paling bungsu yakni Maharaja Diraja yang turun ke pulau emas ini (Bahar Dt. Nagari Basa, 1966)

Dari kalimat tambo itu dapat diartikan bahwa nenek moyang orang Minangkabau adalah keturunan dari tiga orang Maharaja yang bersaudara yakni Maharaja Alif yang berkuasa di Romawi, kemudian adiknya yang nomor dua Maharaja Depang yang menjadi penguasa Cina, dan yang paling muda yaitu Maharaja Diraja yang datang dan menjadi raja di Pulau Emas, yakni nama lain dari pulau Sumatera. Di antara pengiringnya adalah Tjeti Bilang Pandai. Gelar ini semula hanya bagi orang Hindu, namun pada perkembangannya dipakai juga bagi orang asli Minangkabau. Sementara isterinya digelari anak raja, harimau campo, kambing hutan, kucing siam dan anjing yang mualim. Setelah lama berlayar, sampailah di pulau Andalas, pulau Perca. Perahunya tersangkut batu karang dan rusak.

Lebih jauh termuat dalam tambo bahwa tanah air kita ini belumlah terpisah-pisah seperti sekarang, melainkan bersatu dengan Semenanjung Malaya sampai ke tanah Asia. Karena ditimpa oleh topan pada masa Nabi Nuh, hancurlah tanah itu oleh banjir besar yang disebut "kiamat Nabi Nuh". Tanah-tanah yang hancur itu dihanyutkan oleh air surut dan terjadilah selat-selat dan laut-laut yang tidak begitu luas. Pada masa itulah Maharaja Diraja berlayar ke pulau Perca dan mendarat di gunung merapi yang dikatakan masih sebesar telur itik. Pelayaran itu sendiri berawal dari tanah basa (Daratan India) dengan waktu yang lama. Gambarannya termuat dalam Tambo Alam yang mengatakan " dek lamo kalamoan, tampaklah gosong dari lauik, nan sagadang talua itiak, sadang dilamun-lamun ombak " lamakelamaan berlayar ketika mereka sedang timbul tenggelam berjuang menghadapi ombak dan gelombang, tampaklah gosong dari laut, kira-kira sebesar telur itik (gunung Merapi). Adapun tentang keadaan pulau Sumatera ketika mereka datang digambarkan dengan ungkapan pantun : pisau siraiuik bari hulunyo - diasah baru bamato - lautan sajo dahulunyo - mangko banamo pulau paco. Pisau sirauik diberi tangkainya, diasah dulu baru ada matanya. Lautan semua pada mulanya, sekarang bernama pulau Paco (Sumatera).

Dengan demikian menurut tambo nenek moyang orang Minangkabau adalah Maharaja Diraja keturunan Yunani yang berlayar ke Pulau Perca (Sumatera) dari Tanah Basa (daratan India). Pelayaran itu memakan waktu yang lama melewati alunan ombak dan gelombang laut yang besar. Dalam pelayaran itu akhirnya mereka menampak sebongkah daratan yaitu gunung Merapi yang dari kejauhan masih sebesar telur itik. Maka di situlah mereka mendarat. Keadaan alam di sekitar gunung Merapi ketika mereka mendarat masih diliputi air laut. Itulah sebabnya di dalam tradisi lisan 
Minangkabau - siapapun penyusunnya atau penuturnya - selalu dikatakan bahwa asal-usul orang Minangkabau berasal dari gunung Merapi, seperti yang terungkap dalam pantun berikut:

Dimano disalai palito
Dibaliak telong nan batali
Dimano turun niniak kito
Di ateh gunuang Marapi
(B.Dt. Nagari Basa, 1966)
Versi lain pantun ini adalah :
Dari mano titiak palito
Dari tangluang nan barapi
Dari mano asa nenek moyang kito
Dari puncak Gunuang Marapi
(repo.unand.ac.id)
Darimana titik pelita
Dari lentera yang berapi
Darimana asal nenek kita
Dari puncak gunung merapi.

Kedua pantun di atas agak berbeda sampirannya. Namun menunjukkan kesamaan isi, yakni sama-sama mengatakan bahwa nenek moyang orang Minangkabau berasal dari gunung Merapi. Dari sanalah selanjutnya mereka turun ke bawah dan membuat sawah, ladang dan pemukiman.

Tentang hal itu dijelaskan dalam tambo. ... basentak turun ka bawah dibawah labuhan si timbago, lah tibo di guguak ampang, di liggundi nan baselo. Di situlah mulo bataratak, mambuek tampek masiangmasiang, bakeh diam surang-surang, sabalun bakorong jo bakampuang, sabalun bakoto banagari. Di situlah mulo mancancang jo malateh, jolong malambeh jo malamun mako batanao baro bilah. Mako ditarukolah sawah jo ladang, dilambeh hutan jo baluka, dirambah samak jo rimbo dalam, dilambang bumi tanah subur. (B. Dt. Nagari Basa, 1966). Bergerak turun ke bawah di bawah Labuhan Sitimbago, hingga sampai di Guguk Ampang, di Liggundi Nanbaselo. Di situlah awalnya dibangun taratak (pemukiman sederhana) sebagai tempat tinggal masing-masing, sebelum terbentuknya korong dan kampung serta koto dan nagari. Di situ juga mulamula dilakukan merambah hutan dan belukar, membuka lahan, meneruka sawah dan ladang untuk kegiatan bercocok tanam di tanah yang dinilai subur.

Disebabkan bertambuhnya jumlah penduduk maka ditambah pula daerah penghidupan dan pemukiman hingga meliputi daerah yang dinamakan Periangan Padang Panjang. Dan seiring dengan itu maka dibuatlah tatanan sosial dan politik yang dimaksudkan agar masyarakat bisa hidup damai dan tenteram. Tatanan politik adalah menciptakan sistem kekuasaan yang berfungsi untuk karuah mampajaniah yaitu menyelesaikan masalah dan silang sengketa serta menjatuhkan hukuman bagi siapa yang melanggar aturan. Yang menjadi penguasa adalah Maharaja Diraja yang dikatakan sebagai ayam nan barinduak, sifatan siriah nan bagagang. Adapaun tatanan sosial yaitu mengelompokkan ruang kehidupan masyarakat ke dalam tingkatan korong kampung, mulai dari taratak hingga koto dan nagari, serta menciptakan undangundang sebagai pedoman dan rambu-rambu bagi setiap orang dalam kehidupannya di dalam masyarakat.

Pada masa itu ada tiga jenis undang-undang yang berdiri. Pertama, Simumbang jatuah yaitu hukum yang mengatasi masalah sengketa, silang selisih, serta dendam kesumat di dalam koto dan nagari. Sifat keputusannya indak tasangkuik tasampang, indak tasingguang tagaduah, umpamo aie hilia bah hujan jatuah kakasiak. Artinya sifat keputusan hukum ini adalah mutlak dan harus dipatuhi.

Kedua, Si gamak-gamak yakni aturan-aturan tentang kehidupan sosial dan ekonomi. Kok ado karajo nak dikakok ataupun barang nan dibuek, basicapek nak daulu, basikuaek nak manggabiah, mano nan tampak nak diambiak, mano nan ado nak dikarajokan, ndak dikana awa-akhia, raso pareso ndak ditaruah, asa dapek lah manjadi. Sabaiak-baiak pakarjaan saelok-elok aka budi... undang -undang ini menunjukkan kebebasan tak berbatas. Kehidupan berjalan berdasarkan kemampuan diri tetapi tidak memperhatikan etika dan moralitas. Segala aspek kehidupan dijalankan berdasarkan kecakapan, ketrampilan, namun juga berdasarkan perbuatan imoral seperti maling dan penipuan.

Ketiga, Si lamo-lamo adalah aturan yang berdasarkan atas keberanian dan kekerasan. Kebenaran terletak pada siapa yang berani. yaitu babana ka pangka langan, batareh ka ampu kaki, basasi ka ujuang tapak. Kareh makanan takiak, lunak makanan sudu. Kok lai dahan mahambek, dikupak dipatah duo. Kok ado batang malintang,dikarek dikabuang-kabuang, kok tampak rantiang ka mangaik dipatah dipalituakkan. Kok gadang endan-maendan, kok panjang kabek mangabek, nan laweh saok manyaok.

Menurut tambo ketiga undang-undang berubah pada masa kepemimpinan Dt. Suri Dirajo, karena undang-undang ini dinilai kurang berkeadilan karena sifatnya yang tak dapat dibanding, kebenaran tak dapat disebut, sesat tak dapat surut, salah tak dapat minta ampun. Akibatnya banyak orang tak bersalah yang terkena hukumannya, serta banyak orang yang tak berutang yang membayar. Aturan itu bersifat otoriter dan reaksioner dan sering dimanfaatkan untuk menang sendiri. Jikapun suatu fihak berdiri di atas kebenaran jika dia lemah akan berada di fihak yang kalah. Selain itu kurang memperhatikan nilai kemanusiaan, kejujuran, etika, dan moralitas, karena membuka peluang untuk pencurian dan perbuatan curang.

Sebagai pengganti undang-undang tersebut tercipta undang-undang baru yang bernama Undangundang Tariak Baleh. Undang-undang ini mengatur bila terjadi kejahatan, dibalas dengan hukuman yang setimpal dengan perbuatannya. Jika seorang melakukan terbukti melakukan pembunuhan, maka diapun akan dibunuh. Jukan dia memalu (memukul) maka diapun 
akan dihukum dengan cara dipalu. Begitu juga dalam hal hutang-piutang. Jika seorang berhutang dengan emas, maka bayarannya pun dengan emas. Tak boleh dengan barang lain walaupun nilainya sama. Hutang ameh bayia jo ameh,hutang nyawo bayia jo nyawo, hutang padi bayia jo padi, hutang kato bayia jo kato.

Perubahan itu telah membawa perbaikan kehidupan masyarakat. Rakyat yang terdakwa telah dapat mengemukakan perasaanya sebagai hak membela diri, melakukan banding, ataupun menta ampun atas kesalahannya. Sejak itu tumbuhlah dalam masyarakat rasa kasih-mengasihi, turut memikirkan keadaan orang lain dalam pergaulan hidup di korong-kampung atau di koto-nagari.

Seiring dengan itu jumlah masyarakat pun bertambah banyak. Jika semula konsentrasi penduduk hanya berada di bawah gunung Merapi yaitu di Langundi nan baselo, dan Periangan Padangpanjang, selanjutnya pemukiman tersebar di daerah-daerah yang datar yang terletak di sebelah timur dan selatan gunung Merapi yakni daerah- daerah Sungaitarab, Sumanik, Suroaso, Padangganting, Buo, Sumpurkudus, dan lainlain. Kecuali Sumpurkudus semua daerah tersebut sekarang masuk ke dalam daerah yang disebut kabupaten Tanahdatar, nama yang diambil berdasarkan peroses terbentuknya pemukiman pada masa awal sejarah Minangkabau.

Setelah kawasan selatan dan timur gunung merapi telah didiami oleh penduduk yang banyak, dikerahkan pula tenaga untuk menyelidiki alam sekitar utara dan barat gunung Merapi. Ketika ternyata di kawasan tersebut ternyata banyak tanah yang baik untuk ditanami dan dijadikan daerah perkampungan, berangkatlah empat rombongan (kaum) pertama dari Periangan Padangpanjang untuk mencencang dan merambah, membabat hutan untuk dijadikan sawah ladang dan tempat tinggal. Empat rombongan itu sampai disuatu daratan yang lebih rendah dikaki gunung Merapi sebelah utara. Rombangan itu menemukan sebuah lubuk yang mereka namai lubuk Agam di sebuah sungai yang jernih yang hulunya bercabang dua. Yang pertama bernama Sungaijernih, yang kedua bernama Batang Tambuo. Sungai yang mengalir melewati lubuk itu ke hilirnya disebut Batang Agam. Keempat kaum tersebut akhirnya meneruka sawah salang dan membuat pemukiman di daerah-daerah lubuk Agam tersebut. Terbentuklah daerah-daerah yang bernama Biaro, Balaigurah, Lambah, dan Panampuang dan daerah sekitarnya hingga Lasi dan Candung.

Selanjutnya berangkat pula rombongan kedua yang juga terdiri dari empat rombongan kaum, yang masing-masingnya membuat empat perkampungan yaitu Kurai, Banuhampu, Sianok dan Kotogadang. Angkatan ketiga juga terdiri dari empat rombongan kaum, mendiami daerah-daerah yang disebut Sarik, Sungaipuar, Batagak, dan Batupalano. Terakhir adalah angatan keempat yang juga terdiri empat rombongan kaum yang membentuk daerah-daerah di kaki gunung
Singgalang yaitu : Guguak, Tabeksarojo, Balingka dan Koto Pambatan.

Semua daerah itu adalah daerah yang empat angkat, namun dalam perkembangannya daerah-daerah tersebut disebut berdasarkan masing-masing namanya saja. Sedangkan nama Empat Angkat akhirnya hanya melekat pada daerah-daerah yang didiami oleh angkatan pertama. Seluruh daerah tersebut ditambah dengan daerah-daerah lain yang merupakan pengembangannya kemudian menjadi wilayah yang di sebut Luhak Agam.

Setelah Luhak Agam terisi sebagai daerah pemukiman, maka pandangan dialihkan ke kawasan gunung Sago terutama daerah sebelah utara hingga timur. Kawasan ini terdiri dari tanah dataran yang luas, terbentang di sepanjang Batang Limpasi, Batang Sinamar, dan Batang Agam, dan hanya tinggal menanti orang yang akan mengolah saja. Oleh nenek moyang yang berkuasa pada masa itu disiapkan sebanyak 50 keluarga yang akan dipindahkan ke sana. Yang akan dipindahkan itu adalah kaum yang telah berkembang biak tetapi tidak mempunyai harta sawah ladang yang mencukupi untuk memenuhi kebutuhan hidup. Maka dibagilah kaum tersebut ke dalam dua kelompok yaitu kelompok yang akan berpindah, dan kelompok yang akan tetap tinggal di daerah Pariangan Padangpanjang. Meskipun kedua kelompok kaum ini akan terpisah tetapi hubungan kekeluargaan antara mereka tetap seperti sediakala. Tidak terputus antara yang pergi dan yang tinggal. Itulah yang disebut dalam adat Minangkabau panjang bakaratan, laweh basibiran.

Dalam perjalanan mereka menuju kawasan gunung Sago itu, sampailah mereka di pinggir batang Agam dan menyebranginya. Di seberang sungai itu terdapat suatu daratan ( padang ) yang luas dan datar, disana mereka berhenti dan beristirahat. Ketika keesokan harinya rombongan itu bersiap untuk meneruskan perjalanan, mereka menghitung jumlah anggota rombongan. Setelah dihitung ternyata tidak lengkap lagi lima puluh kaum. Sebahagian ahli adat mengatakan jumlah rombongan itu berkurang lima kaum. Kelima rombongan yang hilang tersebut adalah rombongan Datuk Permato Soid di Kuok, Datuk Bandaro Sati di Bangkinang, Datuak Tan Gadang di Salo, Datuk Baramban di Air Tiris, dan Datuk Marajo Basa di Rumbio (https://limapuluhkotakab.go.id/lpk-profildaerah/geografi-dan-demografi). Kelima daerah tersebut terkenal dengan sebutan Kampar Limo Koto dan sekarang masuk ke dalam Kabupaten Kampar Provinsi Riau dan merupakan daerah-daerah penting di kabupaten tersebut.

Keterangan lainnya mengatakan hanya dua kaum. Kaum pertama di bawah pimpinan Dt. Mareko Panjang Janggut meneruskan perjalanan ke Sungai Kampar Kiri dan membangun koto dan nagari di sepanjang sungai tersebut. Kaum kedua yang dipimpin oleh Datuk Mareko Putih Gigi, menghiliri sungai Kampar Kanan dan berkembang biak disepanjang aliran sungai tersebut. Sementara yang lainya membangun perkampungan di 
daerah-daerah: Batuhampar, Tiaka, Airtabit, Anak koto Airtabit, Situjuh, Halaban, Talagogantiang, Taram, Sarilamak, dan Gunung Bungsu. Semua daerah itu termasuk ke dalam wilayah kabupaten Limapuluh Kota sekarang.

Dengan tersebarnya pemukiman penduduk ke daerah-daerah tiga gunung yakni Merapi, Singgalang, Sago, dan sekitarnya maka terbentuklah tiga luhak, yaitu Tanahdatar, Agam, dan Limapuluhkota. Ketiganya merupakan daerah inti dari masyarakat Minangkabau. Ketika jumlah penduduk di ketiga Luhak itu bertambah padat, maka merekapun menyebar ke daerah-daerah sekitarnya, bahkan ke daerah lain melampaui daerahdaerah yang telah lebih dulu ditempati oleh suku bangsa yang lain. Daerah-daerah tersebut disebut daerah rantau.

Orang-orang luhak Tanahdatar membangun daerah rantau ke arah selatan dan tenggara, meliputi daerah Solok dan daerah-daerah sekitar Gunung Talang lainnya. Dari sana mereka turun ke daerah pesisir bahagian selatan yaitu daerah Padang, dan derah-daerah lain di sepanjang pantai hingga daerah Muko-muko di propinsi Bengkulu yang disebut Bandar sepuluh. Daerah-daerah itu dikenal dengan sebutan Rantau Alam Surambi Sungai Pagu, Rantau Duobaleh Koto dan Rantau Pasisia Panjang.

Yang ke arah Tenggara menyusuri Batang Kuantan dan mendirikan perkampungan di sepanjang sungai tersebut hingga ke batas Rengat sekarang. Daerah-daerah tersebut yaitu Lubuak Ambacang, Lubuak Jambi, Gunuang Koto, Benai,Pangian, Basra, Sitinjua, Kopa, Taluak Ingin, Inuman,Surantiah, Taluak Rayo, Simpang Kulayang, Aia Molek, Pasia, Ringgit, Kuantan, Talang Mamak, dan Kualo Thok. Keseluruhan daerah tersebut disebut Rantau nan kurang aso duo puluah.

(https://id.wikipedia.org/wiki/Orang_Minangkabau).

Luhak Agam bergerak ke arah barat dan utara mendirikan perkampungan di Pariaman dan Pasaman yang disebut Rantau Luhak Agam. Daerah-daerahnya mencakup: Tiku, Gasan, Aua Malintang, Malai Sungai Garinggiang,Sungai Limau, Limo Koto (Padang Alai, Kudu Gantiang,Limau Puruik, Sikucua, dan Cimpago), Tujuah Koto (Tandikek, Sungai Durian, Batu Kalang, Koto Dalam, KotoBaru, Sungai Sariak, dan Ampalu), Pariaman,NanSabarih,Ulakan, Anduriang Kayu Tanam, Guguak Kapalohilalang, Duo Kali Sabaleh Anam Lingkuang Sicincin, Pakandangan, Parik Malintang, Sintuak Lubuak Aluang, Kasang, Katapiang, dan Rantau Pasaman. Dari pasaman kawasan rantau Luhak Agam diperluas hingga memasuki daerah-daerah aliran sungai Rokan yang termasuk ke dalam kabupaten Rokan Hulu sekarang. Daerah-daerah tersebut disebut dengan Rantau Nan Tigo Kabuang Aia. Bahasa, suku, dan adat istiadatnya mirip dengan yang terdapat di daerah Rao Kabupaten Pasaman (https://id.wikipedia.org/wiki/Kabupaten_Rokan_Hulu\# Penduduk).
Luhak Limapuluh Kota mengembangkan rantaunya ke arah timur mengiliri sungai Kampar dan sungai Siak, bahkan menyebrangi selat Malaka. Di sana mereka membangun negeri yang disebut Negeri Sembilan dan diperintah seorang raja yang diutus dari Pagaruyung. Meskipun ada yang berasal dari Tanahdatar, paling banyak nama sebutan suku-suku yang ada di Negeri Sembilan diambil dari nama-nama daerah di Lima puluh Kota yang merupakan daerah asal mereka. Misalnya suku Payakumbuh, Sarilamak, Simalanggang, Batuhampar. Mungkal, Tiga batu ( Tiga batur Situjuh ).

Hingga di sini tambo seakan berhasil memberikan gambaran tentang masa lampau masyarakat Minangkabau mulai dari tahap awal hingga tersebar ke berbagai daerah yang cukup luas cakupannya. Namun sebagaimana yang dijelaskan sebelumnya keterangan tambo sangat lemah dalam hal kronologi. Dari seluruh rangkaian proses itu tak terdapat cantuman waktu yang menentukan kapan terjadinya suatu peristiwa beserta urutannya. Untuk itu keterangan-keterangan yang terdapat dalam tambo sebisa mungkin disinkronkan dengan keterangan lain yang disampaikan oleh para ahli arkeologi, antropologi, filologi, dan lain-lain. Dalam hal waktu kedatangan umpamanya, dapat dikatakan bahwa waktunya abad ke 4 sebelum Masehi. Data sejarah mencatat kehidupan Alexander Agung yang disebut Iskandar Zulkarnain itu hidup. Waktu itu juga sinkron dengan zaman bercocok tanam atau zaman perundagian, karena diawal kedatangan mereka dikatakan telah merambah hutan, meneruka sawah dan ladang, membuat pemukiman, dan mengunakan peralatan seperti pedang. Data arkeologis menunjukan bahwa di daerah kabupaten 50 kota sekarang banyak ditemukan benda-benda zaman perundagian seperti menhir, dan dolmen.

Yang memancing persoalan seluruh tambo uraiannya dilengkapi kata-kata dan konsep-konsep Islam, seperti kata Allah SWT, Bismillah, kutipan ayatayat Al Quran dan hadist. Pertanyaannya apakah kedatangan dan kehidupan Masyarakat Minangkabau baru mulai sejak kedatangan Islam ? Jawaban yang mungkin tepat adalah "tidak". Rupanya tambo baru mulai ditulis orang setelah masyarakat Minangkabau mengenal budaya tulisan. Dan itu setelah masa kedatangan Islam. Sebelumnya pemaparannya hanya secara lisan dan turun-temurun. Karena tujuan tambo sifatnya geneologis dan pedagogis, maka pengungkapan masa lampau secara objektif menjadi kurang penting, atas dasar itulah penjelasan tambo dipengaruhi oleh konsep-konsep Islam, karena masa itu agama Islam telah dijadikan pandangan hidup masyarakat Minangkabau.

\section{Sistem Sosial dan Pemerintahan}

Menurut Mestika Zed (2010) secara teori nagarinagari tradisional Minangkabau yang beragam itu, hidup bagaikan republik-republik kecil yang otonom, dalam ha1 ini, mencakup entitas geografis, tradisi adat dan sistem politik yang berbeda-beda. Pepatah adat 
mengatakan adat selingkaran nagari. Artinya masingmasing nagari berbeda-beda adat istiadatnya. Perbedaan itu juga tercermin dalam tanatan adatnya (i) Kelarasan Bodi-Caniago yang menganut adat keperpatihan dan (ii) Kelarasan Koto Piliang, yang menganut adat ketemanggungan. Yang pertama dianggap lebih demokratis, sedang yang kedua lebih aristokratik dan hirarkhis.

Di luar kawasan inti (Luhak) terdapat kawasan rantau. Perbedaan antara kedua kawasan ini lebih kontras sebagaimana terungkap dalam pepatah adat Minangkabau: nagari bapenghulu, rantau barajo (nagari seperintah penghulu, rantau diperintah raja). Artinya nagari-nagari tradisional Minangkabau berada di bawah otoritas penghulu, sementara daerah rantau diperintah oleh bangsawan-bangsawan setempat, diistilahkan dengan "raja", yang menurut tradisi adalah juga keturunan raja-muda yang dikirim dari keluarga Kerajaan Pagaruyung.

Jika dihitung berdasarkan keterangan tambo, tersebut empat orang raja yang pernah memerintah Minangkabau sebelum adanya sumber tertulis. Keempatnya yaitu Datuk Maharajo Dirajo, Datuk Suri Dirajo, Datuk Maharajo Nan Banego-nego, dan Datuk Ketumanggungan yang memerintah bersama adiknya Datuk Perpatih Nan Sabatang. Namun demikian bukan berarti raja yang pernah memerintah hanya empat orang saja. Nama keempat orang itu di sebutkan karena masa pemerintahan mereka adalah momentum penciptaan undang-undang yang diterapkan dalam mengatur masyarakat. yaitu tiga undang-undang awal, undangundang tarik balas dan undang-undang sistem musyarawarah/mufakat yang disusun oleh Datuk Ketumanggungan dan Datuk Perpatih Nan Sabatang. Adapun masa ketika diberlakukannya masing-masing undang tersebut memerintah sejumlah raja, namun tidak disebutkan dalam tambo.

Raja pertama, berdasarkan pada keterangan tertulis adalah Dipunta Hiyang Sri Jayanasa yang memerintah pada abad ke 7. Pernyataan ini berdasarkan pada prasasti Kedukan Bukit yang petikannya sebagai berikut:

....Dipunta Hyang manalap siddhayatra dengan perahu pada tanggal 11 paro terang (sulapaksa)bulan waisaka, tahun 604 S (23 April 682 M) Pada tanggal 7 paro terang bulan Jyestha (19 Mei 662, Dipunta Hyang berangkat dari Minanga membawa tentra dua laksa dan 200 peti kosa perbekalan dengan perahu serta 1312 orang tentara berjalan di darat datang di suatu tempat bernama....Pada tanggal paro terang bulan Asadha (16 Juni 682) dengan suka cita mereka datang di suatu tempat dan membuat kota (wanua) dan kerajaan Sriwijaya memperoleh kemenangan, perjalannya berhasil dan seluruh negeri memperoleh kemakmuran.. (Marwati Djoened Poesponegoro, 1992).
Ahli pubakala Poerbatjaraka menafsirkan kata Minanga (Tamwan) itu adalah Minangkabau, dan menurutnya dahulu ada seorang besar dari Minangkabau pergi berperang, berhenti lebih dulu di Jambi, lalu terus ke Palembang dengan mendapat kemenangan lalu membuat kota di daerah itu yang diberi nama Sriwijaya (Marwati Djoened Poesponegoro, 1992). Jika benar apa yang dijelaskan oleh Poerbatjaraka di atas maka pada abad ke 7 di Minangkabau sudah berdiri sebuah kerajaan yang kuat namun pusat kekuasaannya oleh Dipunta Hyang dipindahkan ke Palembang. Pemindahan tersebut kemungkinan didasarkan pada pertimbangan lokasi pusat pemerintahan ke tempat yang lebih strategis dlam kaitannya dengan jalur lalu lintas perdagangan internasional.

Raja selanjutnya yang berdasarkan keterangan tertulis memerintah di Minangkabau yaitu Aditiyawarman, berkuasa antara tahun 1347-1375. Dia adalah keturunan darah rantau, campuran Minang dan Majapahit (Jawa) yang pulang kampung ke Minangkabau pada tahun 1339. Kala itu sistem pemerintahan yang bersifat independen di bawah penghulu, sudah berdiri mapan di nagari-nagari. Setelah memeluk agama Islam, raja-raja Pagaruyung sepeninggal Adityawarman mulai membangun struktur kerajaan yang memiliki kaki ke bawah. Pucuk kekuasaan teringgi dipegang oleh Raja Alam berkedudukan di Pagaruyung. Raja Alam dibantu oleh dua orang raja untuk urusan adat dan agama. Yang pertama disebut Raja Adat, berkedudukan di Buo, dan yang kedua disebut Raja Ibadat berkedudukan di Sumpurkudus. Ketiga raja itu lazim disebut dengan sebutan Raja Tiga Selo. Di bawah raja-raja tersebut berdiri lembaga yang disebut Basa Ampek Balai, yaitu yaitu semacam lembaga kementrian yang dipimpin empat orang besar 'big man' yang bertanggung jawab dalam urusan adat, agama, militer dan perekonomian. Masing-masing dipegang oleh (i) Datuk Bandaharo, berkedudukan di Sungai Tarab (urusan adat); (ii) Tuan Kadi di Padang Ganting (urusan agama): (iii). Datuk Indomo di Saruaso (urusan ekonomi). (iv) Datuk Makhudum di Sumanik (Urusan keamanan (militer) dengan Tuan Gadang di Batipuah sebagai panglima angkatan perang. Keempat lembaga inilah yang mengurus perkara-perkara di bidangnya masing-masing di seluruh kawasan di Luhak dan Rantau (Mestika Zed, 2010).

Minangkabau tumbuh sebagai kerajaan besar di Sumatera pada masa pemerintahan Adityawarman. Wilayah kekuasaannya meliputi daerah inti Provinsi Sumatera Barat sekarang ditambah daerah-daerah yang sekarang masuk ke dalam wilayah-wilayah provinsi Riau, Jambi, Sumatera utara, Aceh dan Bengkulu. Menurut Tome Pires (2016), tanah Minangkabau selain dataran tinggi pedalaman Sumatra tempat di mana rajanya tinggal, juga termasuk wilayah pantai timur Arcat (antara Aru dan Rokan) ke Jambi dan kota-kota pelabuhan pantai barat Panchur (Barus), Tiku dan 
Pariaman Dari catatan tersebut juga dinyatakan tanah Indragiri, Siak dan Arcat merupakan bagian dari tanah Minangkabau, dengan Teluk Kuantan sebagai pelabuhan utama raja Minangkabau tersebut. Namun belakangan daerah-daerah rantau seperti Siak, Kampar dan Indragiri kemudian lepas dan ditaklukkan oleh Kesultanan Malaka dan Kesultanan Aceh.

Wilayah ini dapat dilacak dari pernyataan Tambo (legenda adat) berbahasa Minang ini sebagai berikut: Dari Sikilang Aia Bangih hingga Taratak Aia Hitam. Dari Durian Ditakuak Rajo hingga Sialang Balantak Basi

Sikilang Aia Bangih adalah batas utara, sekarang di daerah Pasaman Barat, berbatasan dengan Natal, Sumatra Utara. Taratak Aia Hitam adalah daerah Bengkulu. Durian Ditakuak Rajo adalah wilayah di Kabupaten Bungo, Jambi. Yang terakhir, Sialang Balantak Basi adalah wilayah di Rantau Barangin, Kabupaten Kampar, Riau sekarang.

Secara lengkapnya, di dalam tambo dinyatakan bahwa Alam Minangkabau (wilayah Kerajaan Pagaruyung) adalah sebagai berikut:

Nan salilik Gunuang Marapi ( daerah Luhak nan tiga yakni kabupaten Tanahdatar, Agam dan Limapuluh Kota sekarang).

Saedaran Gunuang Pasaman (Daerah sekeliling Gunung Pasaman)

Sajajaran Sago jo Singgalang (daerah sekitar Gunung Sago dan Gunung Singgalang)

Saputaran Talang jo Kurinci (Daerah sekitar Gunung Talang dan Gunung Kerinci) Dari Sirangkak nan Badangkang (Daerah Periangan Padang Panjang)

Hinggo Buayo Putiah Daguak (daerah Muko-muko sekarang masuk Provinsi Bengkulu)

Sampai ka Pintu Rajo Hilia (Daerah Jambi sebelah barat)

Hinggo Durian Ditakuak Rajo (Daerah Perbatasan Jambi)

Sipisak-pisau Hanyuik (Daerah Indragiri Hulu hingga Gunung Sahilan Kampar)

Sialang Balantak Basi (daerah sekitar Gunung Sahilan dan Singingi).

Hinggo Aia Babaliak mudiak (Mudiak daerah rantau pesisir sebelah timur yaitu daerah rantau Palalawan)

Sailiran Batang Bangkaweh (Daerah Singkarak dan aliran Batang Ombilin)

Sampai ka ombak nan badabua (Sampai ke Samudera Hindia)

Sailiran Batang Sikilang (daerah sepanjang Batang Sikilang di Air Bangis)

Hinggo lauik nan sadidieh (sampai ke lautan Hindia) Ka timua Ranah Aia Bangih (daerah sebelah timur Air Bangis )

Rao jo Mapek Tunggua (Daerah Rao dan Mapat Tunggul)

Gunuang Mahalintang (Daerah sekitar Gunung Malintang di Pasaman)
Pasisia Banda Sapuluah (daerah Pesisir Selatan)

Taratak Aia Hitam (daerah Muko-muko di Bengkulu) Sampai ka Tanjuang Simalidu (Daerah perbatasan dengan Jambi)

Pucuak Jambi Sambilan Lurah (daerah pegunungan di Jambi sebelah barat).

Selain itu dikenal pula wilayah pengaruh politik Kerajaan Pagaruyung yaitu wilayah tempat hidup, tumbuh, dan berkembangnya kebudayaan Minangkabau. Pengaruh kerajaan Pagaruyung melingkupi hampir seluruh pulau Sumatra seperti yang ditulis William Marsden dalam bukunya The history of Sumatra (1784). Beberapa kerajaan lainnya di luar Sumatra juga mengakui kedaulatan Pagaruyung, walaupun bukan dalam hubungan pemberian upeti. Ada sebanyak 62 hingga 75 kerajaan kecil di Nusantara yang menginduk pada Pagaruyung, yang tersebar di Filipina, Brunei, Thailand, dan Malaysia, serta di Sumatra, Nusa Tenggara Timur dan Nusa Tenggara Barat di Indonesia. Hubungan tersebut dibedakan berdasarkan gradasi hubungan, yakni sapiah balahan (garis keturunan perempuan), kuduang karatan (garis keturunan laki-laki), kapak radai, serta timbang pacahan yang merupakan keturunan kerajaan.

\section{Minangkabau dan Asal-usul Kesultanan Jambi}

Sumber-sumber Minangkabau tidak terlalu banyak menerangkan tentang hubungannya dengan Jambi. Keterangan tentang Jambi terdapat dalam tambo yaitu pada bagian nasihat Datuk Ketumanggungan pada rakyat Minangkabau terutama laras Koto Piliang :

... Maka berkata Datuk Ketumanggungan kepada Laras Koto Piliang, peganglah kata hamba sembilan patah oleh raja dan penghulu. Pertama dirikan kerajaan di Bukit Batu Patah, kedua dirikan kerajaan di Saruaso, keempat dirikan kerajaan di Padang Ganting, kelima dirikan kerajaan di Sumanik, keenam dirikan kerajaan di Rantau Cati nan Batigo, dirikan kerajaan di Bandar Padang supaya jinak Walanda akan maisi mas manah pada kita, ka salapan dirikan kerajaan di tanah Jambi akan maisi emas manah kepada kita, ka sambilan dirikan kerajaan di tanah Palembang supaya lalu perahu ke tanah Jambi, dari pada lalu tanah Jambi kepada kita. Dan lagi pula dirikan kerajaan pada negeri Siak supaya lalu perahu pada negeri kita dan lagi pula dirikan kerajaan pada negeri Rambah Tambesi dan Rokan Pandalaian supaya jinak segala hamba rakyat Daulat Yang Dipertuan barang kemana berjalan. Maka dirikan pula kerajaan di tanah Aceh seorang supaya boleh orang (pergi) naik haji ke Mekah dan Medinah segala rakyat Daulat Yang Dipertuan. Itulah amanatku (Jamaris, 1991).

Dirikan kerajaan di tanah Jambi... Palembang.. Siak.. Rambah Tembesi.. Pandalaian .. Rokan.. Aceh.. artinya tegakkan kekuasaan di seluruh pulau Sumatera. Daerah-daerah itu disebut Rantau.Jambi dan Palembang terletak di daerah selatan Sumatra. Siak, Rambah 
Tembesi, Rokan Pandalaian terletak di provinsi Riau bagian tengah Sumatra, dan Aceh terletak di bagian paling utara pulau Sumatera.....hal ini sejalan dengan epesode XXIV yan menceritakan bahwa raja-raja di Aceh, Bintan, Jambi, Palembang, Inderapura, dan Indragiri adalah keturunan Daulat Yang Dipertuan Pagaruyung (Jamaris, 1991).

Pada penjelasan episode XXIV yaitu pada bab Sultan Negeri Jambi dikatakan bahwa : ...Sultan negeri Jambi yang bernama Sultan Baginda Tuan anak yang Dipertuan di negeri Pagaruyung jua adanya. Inilah mulamula jadi raja di negeri Jambi, melimpah ke Batanghari lalu ke Riau adanya (Jamaris, 1991).

Keterangan Tambo Minangkabau di atas menyebutkan nama yang berbeda dengan sumbersumber yang umumnya digunakan di Jambi, yaitu tentang nama raja yang mula-mula memerintah di Jambi. Legenda kerejaan Jambi umumnya mengatakan bahwa raja pertama yang memerintah adalah Putri Selaro Pnang masak. Tapi kemungkinan apa yang tersebut dalam tambo Minangkabau tersebut mengacu pada raja lakilaki yang memerintah di tanah Jambi pada masa-masa awal. Namun terlepas dari perbedaan sebutan naman tersebut, seluruh sumber-sumber sejarah Jambi dan Minangkabau sama-sama menjelaskan bahwa raja-raja yang memerintah di Jambi keturunan dari Daulat Yang Dipertuan Pagaruyung.

Di dalam Undang-undang Piagam dan Kisah Negeri Jambi karangan Ngebi Sutho Dilago Periai Rajo Sari (1982), dikisahkan bahwa tatkala meninggalnya Tun Telanai, daerah Jambi tidak lagi mempunyai raja. Sehubungan dengan itu maka turunlah ke Jambi anak raja Pagaruyung yang bernama Putri Selaro Pinang Masak untuk menjadi raja dan mendirikan pusat kekuasaanya di Tanjung Jabung. Disebutkan bahwa ayah Putri Selaro Pinang Masak bernama Raja Beramah. Selain Putri Selaro Pinang Masak, raja Beramah punya dua anak perempuan yang berusia lebih muda yaitu Tuan Putri Panjang Rambut, dan Tuan Putri Bungsu.

Tak lama setelah memerintah di Jambi (Tanjung Jabung), Putri Selaro Pinang Masak menikah dengan Datuk Paduko Berhalo, yaitu anak raja dari Negeri Istanbul (Turki). Dari perkawinan itu lahir empat orang anak yaitu, mulai dari yang paling tua Orang Kayo Pingai, Orang Kayo Kedataran, Orang Kayo Hitam, dan yang paling muda perempuan bernama Orang Kayo Gemuk.

Putri Panjang Rambut menikah dengan sesama keluarga raja Pagaruyung juga punya anak empat orang. Yang tua bernama Sunan Muaro Pijoan, selanjutnya Sunan Kembang Sari, Sunan Pulau Johor dan yang paling muda sekali prempuan tak disebutkan namanya menjadi istri Orang Kayo Hitam.

Putri Panjang Rambut mengikut kakaknya Putri Selaro Pinang Masak berpindah dari Pagaruyng ke Jambi. Keturunan kedua orang putri inilah yang menjadi cikal-bakal bangsawan Jambi yang disebut bangsa XII.
Adapun Putri Bungsu tetap tinggal di Pagaruyung, dan naik tahta kerajaan bergelar Tuan Gadis. Dialah yang memegang hukum adat dan hukum syarak di Koto Besar yang berpagar ruyung. Rumah kerajaannya (Istana) bernama Silindung Bulan dan dan rangkiangnya Sitinjau Laut.

Berdasarkan catatan M.M.H Mennes yang termuat dalam kolonial instituut disebutkan bahwa zaman dahulu kala (kemungkinan sekitar tahun 1440 an ) ada seorang raja yang bersemayam di sekitar Sabak bahagian pantai yang di sebut Tan Telanai. Dia berkeinginan untuk memperistri putri raja Minangkabau yang berkedudukan di Tanjungbungo (Pagaruyung) Batusangkar, namun ditolak oleh putri tersebut melalui sebuah siasat. Putri itu bernama Putri Selara Pinang Masak. Dalam ranji kerajaan Minangkabau disebut Puti Salareh Pinang Masak. Dikatakan bahwa dia bersedia menerima pinangan Tun Telanai dengan sejumlah syarat antara lain : Pertama, melihat terlebih dahulu kerajaannya. Kedua, Ia minta dibuatkan istana khusus baginya dalam tempo satu malam, yaitu harus siap sebelum ayam berkokok. Jika sekiranya syarat-syarat itu tidak terpenuhi maka perkawinan akan batal. Tun Telanai tak kesulitan untuk memenuhi persyaratan pertama, tetapi tak dapat memenuhi syarat yang ke dua. Sebenarnya dengan kemampuannya Tun Telanai bisa saja menyiapkan istana tersebut sesuai dengan waktu yang ditentukan, namun ketika istana tersebut hampir selesai Putri Pinang Masak pelan-pelan ke luar rumah dengan membawa sebuah colok (obor) sehingga menyebabkan ayam berkokok. Sehingga perkawinan itu pun batal. Namun karena rasa cintanya, walaupun gagal memperistri Putri Selaras Pinang Masak raja tersebut mengakuinya sebagai anak yang berhak mewarisi kerajaannya kelak setelah dia meninggal.

Dikisahkan bahwa Tun Telanai meninggal belasan tahun kemudian, dibunuh oleh putranya yang dia buang ke laut disebabkan ramalan ahli nujum yang meramalkan bahwa anaknya itu kelak akan membunuhnya. Ramalan itu rupanya terbukti. Putranya itu tidak sampai meninggal karena terdampar ke pantai Siam dan diambil sebagai anak oleh raja Siam. Dia mendatangi ayahnya dan membunuhnya dengan alasan telah menelantarkan dan membuangnya. Setelah berhasil membunuh ayahnya ia terus ke mudik menemui Putri Selaras Pinang Masak dan menyerahkan kerajaan ayahnya. Setelah itu ia kembali ke Siam dan udmembawa seluruh rakyatnya sehingga tanah kerajaan itu menjadi hutan belukar.

Putri Pinang Masak yang telah menerima peyerahan kerajaan sesuai dengan amanah Tun Telanai, berangkat ke daerah Sabak dengan rakyat banyak. Di samping itu juga diikuti oleh tiga saudaranya yaitu Sunan Muara Pijoan, Sunan Kembang Sari, dan Sunan Pulau Johor. Dari tiga sunan inilah berkembang keturunannnya yang disebut Bangsa XII.

Beberapa tahun setelah Putri Pinang Masak menjadi raja di Ujung Jabung, ia menikah dengan Datuk Paduka Berhala, yaitu seorang asing yang terdampar di 
pulau Berhala karena kapalnya pecah di selatan Pulau Singkep. Dikatakan bahwa orang tersebut berasal Konstantinopel, anak Sultan Turki yakni Sultan Zainal Abidin bin Hasan binti Fatimah binti Muhammad Rasulullah (Mukty Nasruddin, 1989).

Suatu versi yang berbeda adalah yang dikemukakan oleh Aulia Tasman (2016). Berdasarkan sumber-sumber yang diambilnya dari naskah tulisan encong Kerinci, tambo-tambo adat Kerinci, terutama tambo adat Jerangkang Tinggi - Pulau Sangkar, terdapat perbedaan uraian tentang sosok Putri Selaro Pinang Masak, tentang siapa suaminya, serta proses dan rute perjalanannya dari Pagaruyung hingga sampai di Jambi.

Tentang silsilahnya dikatakan bahwa Putri Pinang Masak adalah cucu dari Datuk Paduko Berhalo yang berasal dari Minangkabau. Datuk Paduko Berhalo ini oleh Aulia Tasman (2016) diinterpretasikan nama lain dari Adityawarman. Interpretasi ini didasarkan alasan bahwa Adityawarman pemeluk agama Budha yang disembah dan dihormati oleh rakyatnya. Pernyataan ini kemudian dihubungkannya dengan tambo alam Minangkabau dan tambo Indrapura yang menyebutkan bahwa orang tua Putri Selaro Pinang Masak adalah Ananggawarman ( Raja Beramah ) yang merupakan anak dari Adityawarman (Tasman, 2016). Dengan demikian Tasman menolak keberadaan Datuk Paduko Berhalo sebagai suami Putri Selaro Pinang Masak sebagaimana yang tercantum dalam legenda kerajaan Jambi. Datuk Paduko Berhalo yang di dalam silsilah raja-raja Jambi dikatakan sebagai raja Turki putra Zainal Abidin bin Saidina Husein binti Fatimah Zahra binti Muhammad SAW, dinilai hanyalah tokoh mitos. Alasannya berdasarkan urutan kejadian tentang Kerajaan Turki Usmaniah tak ada ruang waktu yang mengatakan bahwa Datuk Paduko Berhalo adalah keturunan ke lima dari Nabi Muhammad SAW

Selanjutnya Aulia Tasman (2016) juga mengutip berkaitan dengan orang tua Putri Selaro Pinang Masak. Pada sebuah naskah tulisan incung yang dijadikannya sebagai sumber oleh dinyatakan bahwa... nenek Paduka Berhala mengadakan anak yang berdua, seorang laki-laki dan seorang perempuan menunggu Periangan Padang Panjang. Yang laki-laki Temenggung, yang perempuan Dayang Bulan. Dayang Bulan kawin dengan Makhudum Jada memperoleh anak Dayang Berani... Dayang pun ada, Makhudum Jada meninggal, lama kelamaan Dayang Bulan hamil tanpa suami. Diketahui saudara kami diusir oleh Temenggung ke negeri yang terletak di hulu Periangan Padang Panjang. Anakpun lahir. Siapa namanya ialah bernama Putri Unduk Pinang Masak Lama-kelamaan maka ada lahir pula anak laki-laki, itulah yang bernama Perpatih Sebatang...

Uraian pada naskah incung di atas jauh berbeda dengan kebanyakan sumber lain yang mengatakan bahwa Putri Pinang Masak adalah anak dari Ananggawarman atau Raja Beramah dengan istrinya bernama Puti Reno Dewi. Putri Pinang Masak adalah yang tertua dari tiga bersaudara. Dua lainnya adalah
Putri Panjang Rambut I, dan Putri Reno Bungsu Silindung Bulan. Nama terakhir menjadi penerus tahta kerajaan di Pagaruyung. Sedangkan Putri Pinang Masak dan Putri Panjang Rambut I turun ke Jambi untuk selanjutnya menurunkan raja-raja dan bangsawan kerajaan Jambi. Jika mengacu pada naskah incung di atas, maka ibu dari Putri Selaro Pinang Masak bukanlah Puti Reno Dewi melainkan Putri Dayang Bulan. Sedangkan Bapaknya bukanlah Ananggawarman atau Raja Beramah, tetapi tak diketahui karena ibunya hamil tanpa suami.

Tentang suami Putri Selaro Pinang Masak menurutnya adalah Dewang Peniting Putrawano yang disebut Raja Keminting atau sebutan lainnya Sigindo Batinting. Sosok ini merupakan cucu dari Hiyang Idrajati ( Suami raja Minangkabau yang ke 4, populer dengan sebutan Bundo Kanduang) yang datang dari Indrapura, buah perkawinan anaknya yang bernama Dang Tuanku dengan Putri Reno Kemuning Mego.

Selanjutnya dalam hal proses kedatangan dan rute perjalanan, terdapat perbedaan rute dan peristiwa selama di perjalanan. Rute perjalanan Putri Pinang Masak menurut Aulia Tasman (2016) adalah dari Pagaruyung melalui Solok Selatan dan Kerinci. Tepatnya melalui daerah sekitar gunung Talang di Solok, terus ke Danau Bento di Kayu Aro, Sungai Penuh dan Pulau Sangkar di Kerinci. Sesampai di Kerinci dia menikah dengan raja Keminting atau Sigindo Batinting. Selanjutnya terjadi peristiwa perperangan dengan kerajaan Palembang dimana Putri Unduk Pinang Masak dijadikan sebagai tawanan raja Palembang. Putri unduk Pinang Masak kemudian berhasil melarikan diri. Namun dalam pelariannya dia tak kembali ke Pulau Sangkar melainkan ke mengiliri Sungai Batanghari melalui Bangko, Muaro Bulian, terus ke Ujung Jabung (Tasman, 2016).

Guna mencari kejelasan sejarah versi Aulia Tasman (2016) ini benyak pernyataannya yang memerlukan pengkajian sejarah lebih dalam karena beberapa interpretasinya harus disesuaikan dengan cara berpikir historis. Pertama, tentang sosok Datuk Paduko Berhalo yang diidentifikasi sebagai Adityawarman. Pernyataan ini perlu didukung data yang cukup dan fakta yang lebih kuat. Pengidentifikasian nama yang ada pada sebuah prasasti, biasanya diambil dari tulisan yang terdapat pada prasasti itu sendiri. Seperti maklumat yang dituliskan pada punggung Arca Amoghapaca, tertulis nama: Udayatiyawarman Pratapaparakarma Rajendra Mauli maliwarmadewa. Atau sebagaimana tercantum dalam prasasti Kubu Rajo No.I, Adityawarman menyebut dirinya sebagai Kanakamedinindra atau Raja Tanah Kanaka. Tanah Kanaka atau "tanah emas" sama artinya dengan Swarnadvipa yang pada waktu itu dipakai untuk menyebut pulau Sumatera. Dalam prasasti Bukit Gombak Adityawarman menamakan dirinya Srimat Sri Adityawarman Pratapaparakrama Rajendramauliwarmadewa Maharajadhiraja (Casparis, 1992). Ada juga gelar yang cukup panjang dalam lidah masyarakat Minangkabau yaitu Dewang Palokamo 
Deowano, lengkapnya Rajo Dewang Palokamo Indo Deowano". Apabila disesuaikan dengan bahasa sanskerta, kata-katanya nama itu menjadi Raja Dewa Palakarma Indra Dewawarma". Selain itu ada pula nama lain yang dihubungkan dengannya yakni Aji Mantrolot. Nama ini diyakini banyak sejarawan sebagai nama kecil dari Adtyawarman. Atau bisa juga berdasarkan sebutan masyarakat sekitar lokasi keberadaan suatu arca atau prasasti sejarah. Masyarakat Sungai Lansek Sumatera Barat tempat ditemukannya arca Amoghapaca menamakan arca tersebut Si Rocok (Amran, 1981).

Kedua, berkaitan dengan asal-usul Putri Selaro Pinang Masak yang dikatakan sebagai cucu dari Dt. Paduka Berhalo dari anaknya yang bernama Dayang Bulan yang kawin dengan seseorang bernama Makhudum Jada. Pasangan ini punya anak bernama Dayang Berani. Namun Mukhudum Jada meninggal taklama setelah Dayang lahir. Lama kelamaan Dayang Berani hamil tanpa suami dan melahirkan seorang anak bernama Putri Unduk Pinang Masak. Aulia Tasman (2016) menyamakan nama ini dengan Putri Selaro Pinang Masak. Jika kisah ini dianggap benar maka Bapak dari Putri Selaro Pinang Masak tidak diketahui. Hal ini sangat berbeda dengan sumber-sumbersejarah lain yang mengatakan bahwa Putri Selaro Pinang Masak Adalah cucu dari Adityawarman, yakni dari putranya bernama Ananggawarman atau dikenal juga dengan sebutan Raja Beramah. Ananggwarman punya anak tiga orang perempuan yaitu Putri Pinang Masak, Putri Panjang Rambut, dan yang paling muda Putri Bungsu (Ngebi Sutho Dilago: 1982, Mukti Nasruddin, 1989, https://id.wikipedia.org/wiki/Ananggawarman).
Ketiga, tentang Raja Keminting atau Sigindo Batinting sebagai suami Putri Selaro Pinang Masak. Jika keterangan ini dilihat dari perspektif geneolagis maka keterangan ini sangat susah dipahami. Berbagai sumber sejarah umumnya menerangkan bahwa Putri Pinang Masak adalah generasi ketiga atau cucu dari Adityawarman. Sedangkan Raja Keminting yang menjadi suaminya adalah generasi ke enam. Raja Keminting adalah cicit dari Putri Reno Bungsu Silindung Bulan yang merupakan adik Putri Selaro Pinang Masak. Puti Bungsu Silindung Bulan menikah dengan Wijayawarman Mauliwarmadewa alias Dewang Pandan Putowano alias YDP Maharaja Sakti I. Pernikahan ini melahirkan anak bernama Pati Panjung Rambut II yang nama lainnya yaitu Bundo Kandung. Puti Panjang Rambut II kawin dengan Indo Jati alias Bujanggo Salamat Panjang Gombak melahirkan anak bernama Dewang Pandan Salasiah Bonang Raiwano alias Dang Tuanku. Dang Tuanku menikah dengan Putri Retno Kemuning Mego alias Putri Bungsu II melahirkan anak Dewang Sari Dewano alias Maharaja Dewana alias YDP Maharaja Sakti II, Sutan Alam Dunia/Dunie. Dikatakan bahwa Dang Tuanku punya anak empat urang salah satunya bernama Dewang Peniting Putrawano alias Raja Keminting, alias Sigindo Batinting yang menjadi Putri Unduk (Selaro) Pinang Masak . Masalahnya terdapat jarak generasi yang amat jauh di antara keduanya. Jika keduanya diurutkan generasinya maka Raja Keminting adalah cicit dari Putri Selaro Pinang Masak. Mungkinkah perkawinan itu terjadi. Untuk lebih jelas dapat diperhatikan dari ranji atau silsilah berikut ini.

Bagan Hubungan Kerajaan Minangkabau dan Kesultanan Jambi

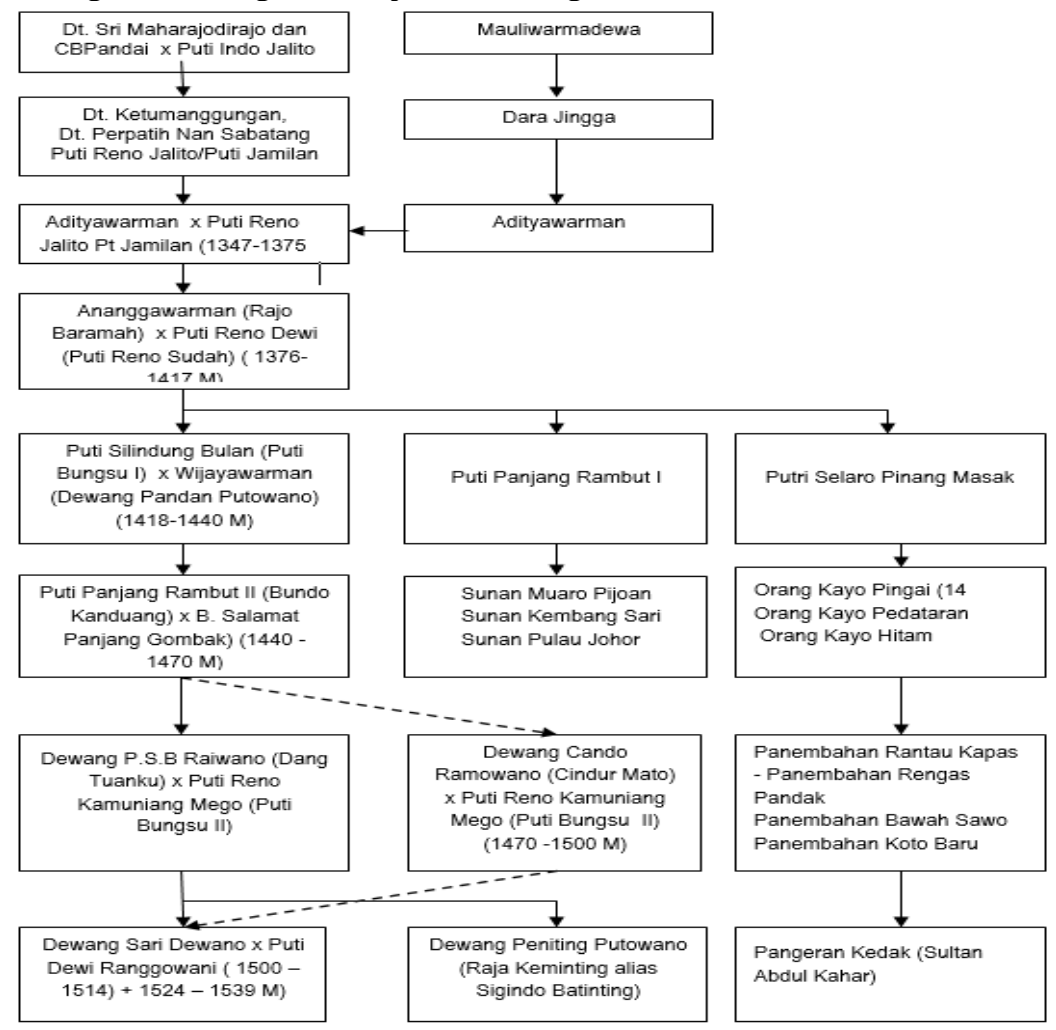


Selanjutnya dalam hal proses kedatangan dan rute perjalanan, terdapat perbedaan rute dan peristiwa selama di perjalanan. Di dalam Undang-undang Piagam dan Kisah Negeri Jambi hanya disebutkan .... tatkalo mati Tan Telanai ini, Jambi tidak berajo lagi. Maka turun anak rajo Pagaruyung ke Jambi perempuan nama Tuan Putri Selaro Pinang Masak (Ngebi Sutho Dilago, 1982). Dalam hal ini secara khusus tidak disebutkan tentang rute perjalanannya. Demikian pula Mukti Nasruddian (1989) hanya menyebutkan Putri Selaro Pinang Masak berangkat ke daerah Sabak dengan diikuti oleh rakyat banyak dan disertai tiga orang saudaranya. Namun berdasarkan kisah yang mengatakan bahwa ketiga saudaranya yang menyertainya tadi kembali ke pedalaman/uluan dan membangun kerajaan-kerajaan kecil di Jujuhan, Sirih Sekapur, dan Tanjung Belit, maka dapat diperkirakan rute perjalanan yang ditempuh adalah rute sepanjang aliran sungai Batanghari. Dasar pikirannya adalah semua daerah tersebut terlelatak di sekitar aliran sungai Batanghari.

Sehubungan dengan uraian di atas maka rumusan masalah yang diajukan dalam penelitian ini adalah berupa pertanyaan, bagaimana keberadaan Kerajaan Minangkabau sebagai asal-usul dari kesultanan Jambi.

\section{SIMPULAN}

Daerah Minangkabau adalah daerah tua dengan sejarah dan kebudayaannya yang tua pula. Daerah ini telah didiami oleh penduduk setidaknya sejak sejak zaman neo-lithikum 2000 tahun sebelum Masehi. Hal ini dibuktikan dengan banyaknya ditemukan peninggalan Menhir yang tersebar di berbagai daerah di Kabupaten 50 Kota Sumatera Barat.

Dari perspektif tradisi lisan Melayu daerah Minangkabau dengan Gunung Merapi nya adalah tempat turunnya Sang Sapurba atau nama lainnya Sir Maharaja Diraja, keturunan Iskandar Zulkarnain yang merupakan cikal-bakal raja-raja yang memerintah di negeri-negeri Melayu di Pulau Sumatera. Sebagai negeri tua Daerah Minangkabau menghasilkan hukum adat istiadat. Datuk Ketumanggungan dan Datuk Perpatih Nan Sabatang dikenal sebagai orang-orang yang merancang dan merumuskan adat Minangkabau. Adat ini kemudian mempengaruhi negeri-negeri Melayu lainnya. Hingga saat ini masyarakat Negeri Sembilan di Malaysia masih mengakui bahwa adat kebudayaan yang mereka jalankan adalah warisan dari Datuk Perpatih Nan Sabatang

Bila dikaitkan dengan Jambi dapat dipastikan kedua daerah ini mempunyai ikatan sejarah dan budaya yang kuat. Dari segi sejarah hubungan kerajaan, dapat dikatakan bahwa Kerajaan Minangkabau adalah sebagai asal-usul dan cikal-bakal kesultanan Jambi. Hampir semua sumber sejarah baik lisan maupun tulisan mengatakan bahwa Putri Selaro Pinang Masak adalah penubuh kerajaan / kesultanan Jambi. Dan dia adalah anak dari Raja Minangkabau yang bernama Ananggawarman atau nama lainnya Raja Beramah. Raja ini mempunyai anak perempuan tiga orang, yang paling tua , Putri Selaro Pinang Masak, kedua Putri Panjang Rambut, dan yang ketiga yang paling muda yakni Putri Putri Silindung Bulan alias Putri Bungsu. Dua yang pertama turun ke Jambi sementara Putri Bungsu tetap tinggal dan memerintah di Minangkabau bersama suaminya Wijayawarman yang bergelar YDP Maharaja Sakti I.

Kedatangan Putri Selaro Pinang Masak tidak hanya membawa kekuasaan politik, melainkan juga sistem hukum dan adat istiadat ynag hingga ini masih tetap berlaku di daerah Jambi. Raden Abdullah seorang tokoh Lembaga Adat Melayu Jambi mengatakan bahwa yang menyusun adat Jambi itu adalah Datuk Perpatih Nan Sabatang dari Pagaruyung (Minangkabau), sedangkan yang berasal dari Bandar Jambi adalah Datuk Ketumanggunan. Sejalan dengan itu Oemar Ngebi Sutho Dilago mengatakan bahwa teliti dari Jambi, undangundang dari Minangkabau. (A Danhuri Mukti, 2008).

\section{DAFTAR PUSTAKA}

A.B. Lapian. 1997. Sejarah Indonesia Penilaian Kembali Karya Utama Sejarawan Asing. Depok. Pusat Penelitian Kemasyarakatan dan Budaya. LPUI.

A. Danhuri Mukti. 2008. Sejarah KabupatenTebo Jambi. Pemkab Tebo

Aulia Tasman. 2016. Menelusuri Jejak Kerajaan Melayu Jambi dan Perkembangannya. Jakarta. Gaung Persada Pers

Bahar Dt. Nagari Basa \& Permato. 1966. Fasafah pakaian penghulu di Minangkabau. Payakumbuh: C.V. Eleonora

Casparis, J. G. DE. 1992. Kerajaan Malayu dan Adityawarman. Makalah disampaikan dalam Seminar Sejarah Melayu Kuno Jambi $7-8$ Desember 1992.

Graves, Elizabeth. 2007. Asal-usul Elite Minangkabau Modern. Jakarta. Yayasan Obor Indonesia

Helius Sjamsuddin. 2007. Metodologi Sejarah. Jogyakarta.Penerbit Ombak.

https://id.wikipedia.org/wiki/Orang_Minangkabau diakses 10 Juni 2020

https://id.wikipedia.org/wiki/Islam_di_Filipina . di akses tanggal 16 Februari 2020

https://id.wikipedia.org/wiki/Datuk_ri_Bandang, diakses 10 Juni 2020

https://id.wikipedia.org/wiki/Datuk Karama, di akses 10 juni 2020

https://id.wikipedia.org/wiki/Datuk_Mangaji diakses 10 Juni 2020

(https://id.wikipedia.org/wiki/Kabupaten_Rokan_Hulu\# Penduduk ) di akses 27 Januari 2021

https://limapuluhkotakab.go.id/lpk-profildaerah/geografi-dan-demografi 10 Juni 2020

https://id.wikipedia.org/wiki/Ananggawarman diakses 10 Juni 2020 
Jamaris, Edward. 1991. Tambo Minangkabau: Suntingan Teks Disertai Analisis Struktur. Jakarta: Balai Pustaka

Koentjaraningrat. 2009. Pengantar Ilmu Antropologi. Jakarta. Penerbit Rineka Cipta

Kompas.com, 22 Juni 2013

Marsden, William, F.R.S. 2016. Sejarah Sumatera.Jogyakarta. Penerbit Indo Literasi

M.D Mansur. 1970. Sedjarah Minangkabau. Jakarta Bharata

Mukti Nasrudin. 1989. Jambi Dalam Sejarah Nusantara. Naskah tidak diterbitkan.

Nana Syaodih. 2009. Metode Penelitian Pendidikan. PT. Remaja Rosdakarya : Bandung. h.52.

Ngebi Suto Dilago Periai Rajo Sari. 1982. Undangundang Piagam dan Kisah Negeri Jambi. Jakarta. Proyek Penerbitan Buku Sastra Indonesia dan Daerah.

Pires, Tome. 2016. Suma Oriental. Jogyakarta. Penerbit Ombak

Pusponegoro, Marwati Joned; Notosusanto, Nugroho. 1992. Sejarah Nasional Indonesia. Jakarta: Balai Pustaka

repo.unand.ac.id

RZ. Leirissa. 1997. Sunda Kelapa Sebagai Bandar Jalur Sutra. Jakarta: Direktorat Jenderal Kebudayaan, Depdikbud

Reid, Anthony. 1992. South-East Asia in The Age of Commers 1450-1680.New Haven London. Yale University Press

Rusli Amran. 1981. Sumatera Barat Hingga Plakat Panjang. Jakarta. Sinar Harapan

Taufik Abdullah. 1985, Ilmu Sejarah dan Historiografi. Jakarta. PT Gramedia.

Vansina, J. 2014. Tradisi Lisan sebagai Sejarah. Yogyakarta: Ombak.

Zed, Mestika. 2010. Pengantar Filsafat Sejarah. UNP Press 